Article

\title{
Vertically Differentiating Environmental Standards: The Case of the Marine Stewardship Council
}

\section{Simon R. Bush ${ }^{\dagger}, *$ and Peter Oosterveer ${ }^{\dagger}$}

Environmental Policy Group, Wageningen University, Hollandseweg 1, Wageningen $6701 \mathrm{KN}$, The Netherlands; E-Mail: peter.oosterveer@wur.nl

$\dagger$ These authors contributed equally to this work.

* Author to whom correspondence should be addressed; E-Mail: simon.bush@wur.nl; Tel.: +31-317-483-310.

Academic Editors: Maki Hatanaka and Douglas H. Constance

Received: 15 October 2014 / Accepted: 5 February 2015 / Published: 10 February 2015

\begin{abstract}
This paper explores the externally-led vertical differentiation of third-party certification standards using the case of the Marine Stewardship Council (MSC). We analyze this process in two dimensions. First, fisheries employ strategies to capture further market value from fishing practices that go beyond their initial conditions for certification and seek additional recognition for these activities through co-labelling with, amongst others, international NGOs. Second, fisheries not yet able to meet the requirements of MSC standards are being enrolled in NGO and private sector sponsored Fisheries Improvement Projects (FIPs), providing an alternative route to global markets. In both cases the credibility and authority of the MSC is challenged by new coalitions of market actors opening up new strategies for capturing market value and/or improving the conditions of international market access. Through the lens of global value chains, the results offer new insights on how such standards not only influence trade and markets, but are also starting to change their internal governance in response to threats to their credibility by actors and modes of coordination in global value chains.
\end{abstract}

Keywords: certification; global value chains; fisheries; eco-labels; NGOs 


\section{Introduction}

As environmental standards have proliferated and diversified scholarly attention has been given to how increasing competition between standards can lead to either a gradual "ratcheting up" of environmental performance [1] or a race to the bottom as certifiers and certification bodies vie for market share [2]. This debate points to the wider political economy of standards, reflecting what Marsden [3] refers to as the "battlefield of quality" in agri-food networks, and the implications of competing values and norms over global production and consumption, e.g., [4,5]. A lesser studied dimension of this competition is the "vertical" differentiation of environmental standards, which we argue occurs in at least two ways. First, standard setting bodies create a range of internal tiers to foster continual improvement within the certification scheme by creating what Tlusty [6] refers to as "pull" towards predefined certification thresholds. In addition, a less well understood process of externally driven "vertical differentiation" of private standards both in an upward direction, creating more stringent standards, and in a downward direction leading to more lenient standards [7,8]. In both directions, we identify this process as initiated by firms situated in global value chains (GVCs) and proceeding outside the control of standard setting bodies.

This paper explores the phenomenon of externally-led vertical differentiation of environmental standards using the case of the Marine Stewardship Council (MSC). Building on an earlier paper [9] that first identified this phenomenon, we analyze how vertical differentiation occurs either after or beyond the certification threshold through what we label "MSC-plus" fisheries, and in yet-to-be-certified or "MSC-minus" fisheries. MSC-plus fisheries attempt to design strategies, such as co-labelling, to capture further market value from additional efforts to make fishing practices more sustainable. MSC-minus fisheries, not yet able to meet the requirements of MSC standards, are being enrolled in NGO and private sector sponsored Fisheries Improvement Projects (FIPs), which in turn provide a potential alternative route to global markets. In both there is not a rejection of the standards, certification process or eco-label by the firms and NGOs involved, but instead an attempt to alter the market position (and power) of the standard through coalitions of value chain actors presenting new or alternative options for market value and/or access. Examining the phenomenon of vertical differentiation of private standards therefore extends the current focus of GVC analysis from the influence of these standards on lead firms [10-12], to the influence of lead firms on the governance and credibility of standards.

Adopting a case study approach, this paper provides analytical generalizations on private credibility and authority using the abstract heuristic of vertical differentiation, see [13]. A mixed-method approach is adopted [14], including the collection and analysis of published case studies and online documentation of companies engaged in MSC certification, FIPs and co-labelling. Additional data was collected through 11 in depth interviews with the MSC, WWF and a selection of related firms based on a topic list generated from the document analysis.

The following section outlines the emergence of private environmental standards and their role in the governance of GVCs. The paper then provides a short description of the MSC, focusing on the on-going challenge it faces to balance scientific credibility with access and continual improvement, before outlining the MSC-plus and MSC-minus cases. Attention is then given to the internal response of the MSC before turning to a discussion of what implication vertical differentiation holds for environmental 
standards and the value chain actors they seek to govern. The paper finishes with some insights into the implications of externally led vertical differentiation of sustainability standards as an emerging phenomenon.

\section{Understanding the Drivers of Standard Differentiation}

\subsection{Quality Standards-Proliferation and (Vertical) Differentiation}

Quality standards have emerged in response to a wider shift in governance away from state-dominated towards private regulation of global commodity production and consumption [15]. The role of standards has gradually evolved from their use as technical guides for communicating product specifications to tools incorporating a wide range of "credence" qualities of a product that cannot be known to distant actors in a market through sensory inspection or observation [2,16]. As sustainability standards have evolved so too has our understanding of how they are used to govern complex issues such as environmental sustainability, e.g., [12,17-22] within the wider architecture of global agro-food networks [23-25].

As an ever wider group of issue advocates have sought to advance their concerns about economic activities through the market, there has been a sustained proliferation of private standard schemes [2,26-28]. For fisheries alone there are more than 30 different standards ranging from organic to fair trade and sustainable [29-31]. This "horizontal differentiation" of standards has drawn considerable academic critique. Standards are seen as posing a new form of non-tariff barriers to trade as producers, especially in developing countries, are unable to comply due to structural inequalities and deficits in firm-level capacity [32-35]. Others have argued, in contrast, that standards can promote new forms of competition, especially for producers in developing countries where compliance to standards is seen as a means to overcome the race to the bottom for labor and environmental conditions and instead promote a "ratcheting up" of performance, $c f$. [1,36,37]. More nuanced analyses have pointed to the influence of standards on the organization and coordination within GVCs [38]; how standards affect the structural distribution of labor and value in global markets [39] as well as the strategic behavior of firms when responding to rewards and/or risks posed by regulated markets [40].

A largely un-explored phenomenon is what we term the "vertical differentiation" of environmental standards. That is, the differentiation of a standard from a simple binary model of certified/non-certified to multiple "tiers" representing degrees of compliance above and below a predetermined certification threshold [6,41]. Such tiered systems are evident for a range of products, such as organic food, palm oil, energy, and free range eggs [42-44]. Following Bush et al. [9] we posit that this vertical differentiation can either be internally or externally driven. A certification scheme may introduce vertical differentiation to acknowledge and claim value on different levels of compliance by suppliers. In other cases, lead firms may set differentiated targets to move suppliers gradually towards a longer-term strategic goal. As Tlusty [6] outlines, if these thresholds are set correctly they create a more realistic incentive-based "pull" to become certified and they can also set incentives for continual improvement beyond certification.

Alternatively, as this paper goes on to describe in further detail, differentiation may also be externally-led, outside the control of the owner of the standard and driven by coalitions of multiple chain actors including lead firms, NGOs and producers. Understanding the process of external vertical differentiation 
therefore opens up questions around how firms and NGOs influence the structure and function of private standards in GVCs.

\subsection{Global Value Chains and Quality Standards}

GVC analysis has moved away from delineating capitalist modes of production and consumption to focus on firm-centered conceptualizations of governance [45]. Governance within value chain analysis is therefore multi-dimensional, positioning the meso-level structural logics of chains and the micro-level analysis of firm upgrading with the wider institutional and structural environments in which value chains are embedded $[10,46]$. In doing so GVC analysis has expanded from a narrow focus on the internal coordination between actors operating in specific segments of chains, as developed by Gereffi [47] and others, to include a wider understanding of the impact of regulation on the way lead firms organize international production networks [48]. However, as variously argued [4,49], attention within this literature has focused mainly on "vertical" dimensions of coordination within value chains, and not on the wider institutional and political governance dynamics that inform how firms operate and coordinate within value chains. As Bair [50] argues, doing so has taken value chain analysis away from the wider institutional and structural environments within which economic activity is embedded.

The focus of GVC analysis has recently taken a new turn that gives greater attention to the existence of multiple and parallel forms of governance in different segments of a value chain [51,52]. Here both GVC scholars, as well as those focused on a Global Production Network (GPN) approach, are converging around a set of questions related to the dynamic interaction of firm and non-firm actors in dealing with value chain governance $[10,11]$. These dynamic interactions are particularly relevant to understanding how non-firm actors and regulatory arrangements external to value chains influence firms embedded within these chains, e.g., [53-56]. By addressing these dynamics both the GVC and GPN approaches are able to maintain their central focus on firm strategy and behavior, but position these firms in wider regulatory and normative networks operating at different scales of interaction, from firm to chain and beyond [10]. Furthermore, by drawing on these wider influences, value chain governance can be explored in terms of the dynamic intersection between the structural dimensions of regulation and the strategic behavior of firms to gain and maintain access to markets.

Focusing on standards as a form of coordination within the value chain builds on earlier formulations of what is termed "normalization" in value chains; where specific practices are realigned to mirror or materialize norms and standards [45,57]. However, from a dynamic perspective it becomes possible to ask not only how firms structure vertical relations in the chain in response to standards, but also how they place demands back on standards. This perspective allows for a broader analysis of how private sustainability standards gain and maintain their traction in the market and how they influence the behavior and coordination strategies of firms in GVCs. How does the strategic behavior of firms and their wider networks, as well as the market dynamics in which they operate, influence the form and function of sustainability standards? In addition, ultimately, how does this strategic behavior influence vertical differentiation within these standards? Borrowing from Yeung and Coe [11], questions also emerge about how standards and firms are related and influence each other, as well as how standards (like firms) evolve over time in response to the feedback they receive. 
Finally, the relational nature of this dynamic approach to understanding the interaction between standards and firm actors also returns to the ongoing challenges private governance arrangements face in generating and maintaining credibility and authority. This in turn opens up a central paradox. When standards adopt a strategy of not engaging and responding to firms, and thereby closing themselves off to external input they risk to undermine trust and inclusiveness; two key ingredients of private, entrepreneurial authority, e.g., [58,59]. However, opening themselves up to this process of co-creation runs other risks, including a watering down of standards by private actors, over-ambitious or unrealistic standards, or increased formalization in the procedures in an attempt to maintain surveillance and control. All of these possibilities bring us [9] back to questions about how credibility can be balanced with the challenge of promoting continuous sustainability improvement through vertical differentiation in standards while at the same time remaining accessible to a wide range of actors.

\section{The MSC: Credibility, Access and Continual Improvement}

Established in 1997 through a partnership between WWF and Unilever, the MSC reflected a wider democratization of concerns around fisheries and seafood in the 1990s that recognized the limitations of state-driven management in regions such as North America and Europe [60,61]. The MSC has grown considerably over the last decade due to a parallel rise in awareness around seafood sustainability leading to increased demand from both consumers and supermarkets. In real terms MSC certified fisheries now represent over $12 \%$ of global stocks, up from $1 \%$ in 2004, and over 22,000 products bear the MSC label in more than 70 countries [62]. Along with its expansion and success the MSC has come under considerable criticism related to its accessibility and its ability to foster continual environmental improvement (described by [9] as an internally confounded "devil's triangle"), directly influencing the scheme's credibility.

As a private sustainability standard, the MSC is underlined by its techno-scientific credibility. The consistency and transparency of the MSC is demonstrated through the three principles that form the basis of its Fisheries Assessment Methodology (FAM): (1) Maintaining the productive capacity of fish stocks; (2) Maintaining the structure, productivity, function and diversity of the ecosystem on which the fishery depends; and (3) Effective management that meets the requirements of laws and standards and operational frameworks that require responsible and sustainable use of fish stocks [63]. Each of the principles is further broken down into criteria that specify requirements that have to be met for certification. Finally, these criteria are interpreted as principle indicators (PIs) that form the basis of the metric-based performance range for certification with three "scoring guideposts": a "perfect" fishery represented by the score of 100; a score of 80 for acceptable and unconditional performance; and a minimum score of 60 indicating conditional compliance with the MSC standard [64]. The weighted average of all PIs must achieve 80 or more for each of the principles to become certified. The PI scores are therefore the fundamental determinants of credibility, as they represent the sustainability of a fishery under assessment.

The credibility built up by the MSC through this procedure has come under considerable pressure through two distinct criticisms. First, the MSC is seen as largely inaccessible for small-scale and developing world fishers because of the organizational, administrative and financial burden of the certification process $[31,65,66]$. The consequences of their "exclusion" are considerable given the 
contribution of these fisheries to global catch and North-South trade [67]. Changes proposed to the FAM during the 2012 review were partly aimed at simplifying and reducing the cost of the assessment process. However, as simplification cannot come at the expense of rigor, maintaining the credibility of the MSC means that involvement of any fishery is contingent on compliance with MSC's robust and consistent procedures.

The second main criticism is that the MSC has not led to a measurable reduction of fish stock decline [68] and that overfished stocks continue to be certified [69]. Critics have maintained that, on the one hand, the continual improvement of overall environmental performance has been complicated by an inflexible interpretation of the assessment process and the certification of only the best performing fisheries [64]. In response the MSC has argued that fisheries that receive a cautionary recommendation to proceed to full assessment, or that pass full assessment with conditions, are forced to meet specified requirements set out in monitored action plans [70,71]. This is supplemented by the MSC in its recent impact report [72], which shows that the proportion of fisheries that scores over 80 percent has been increasing since 2008 as the obligatory action plans for the fisheries that scored between 60 and 80 have been completed. However, the report also shows that the largest gains are most likely to be made by the $65 \%$ of fisheries that do not even make it through to full assessment (see Figure 1). As summarized by Ponte [61], this has led to a central dilemma for MSC: maintain the stringency required to stimulate continuous improvement in those fisheries that are already certified, but also provide adequate incentives for the worst performing fisheries to enter into an assessment.

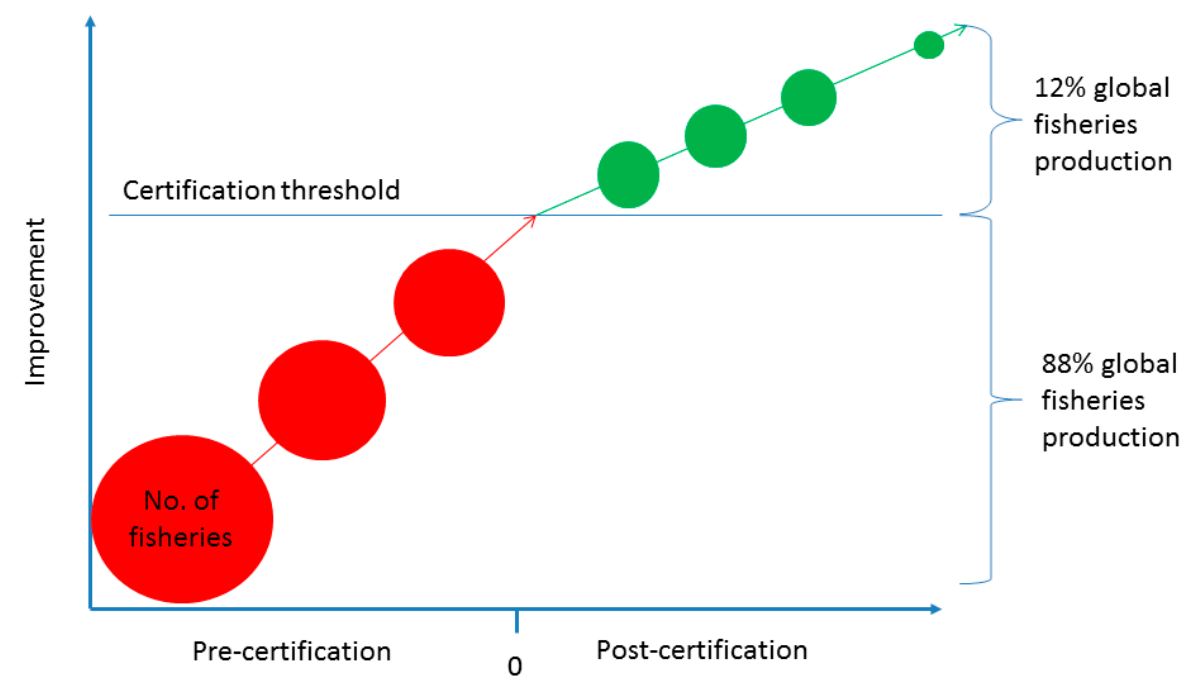

Figure 1. Schematic of Principle Indicator Score improvement pre and post certification. Adapted from Cambridge et al. [70].

One proposed response to this dilemma is the introduction of a tiered approach to certification that would allow the MSC to reconcile the substantive aspects of sustainability with the procedural issues of access and equitability [6,9]. In practical terms a tiered approach would mean moving away from the 80 PI certification target and create multiple thresholds, for example at 40, 60, 80 and 95 PI targets (and in the future perhaps 110). By doing so the MSC would extend their influence over those fisheries outside the pre-assessment threshold. The main counter-argument to adopting such a system is that accommodation of a wider range of fisheries would be perceived as an erosion of the already rigorous 
science-based standard. However, as we now go on to argue, the danger of not addressing this dilemma has already been taken up by those disaffected by the certification process through what we label externally led vertical differentiation, which is further challenging the MSC to internalize these challenges in the tools and governance structure of the organization.

\section{Externally-Led Vertical Differentiation}

Two sets of cases illustrate the process of externally led vertical differentiation and how quality standards not only influence, but also are influenced by the coordination in the value chain and firm strategies. The first set is labelled "MSC-plus", including examples of firms seeking (symbolic and market) value beyond the minimum requirement for certification through co-labelling with international NGOs. The second set is labelled "MSC-minus" and includes examples of firms, through fishery improvement projects (FIPs), seeking market access whilst below the MSC certification threshold.

\subsection{MSC-Plus: Co-Labelling for Value Endorsement}

Co-labeling MSC certified products with other eco-labels or NGO logos has occurred intermittently in different consumer markets, as outlined in Table 1. The stated intention of these co-labelling strategies by NGOs is to support the MSC, especially in markets where recognition of the "blue tick" label remains low $[73,74]$. However, we argue that this strategy, over which the MSC has no control, holds both opportunity and risk. While some firms may perceive co-labelling as a support strategy, co-labelling may also be seen as a strategy to address the perceived limitation of the MSC "blue tick" to adequately communicate the investments made in sustainability to consumers.

The examples of co-labelling summarized in Table 1 are most commonly associated with the WWF Panda logo - one of the most widely recognized non-profit brands. In each of these cases respondents outlined how the addition of the WWF Panda on MSC labelled products communicates a strategic alliance between the brand or retailer and WWF. In Germany, a market with high consumer recognition of the MSC label, the Edeka supermarket chain has co-labelled its MSC certified home-brand products to advertise its support of "sea protection projects" through WWF. In support of Edeka's goal to only sell sustainable fish in 2015 WWF has licensed their Panda logo for use on MSC labelled Edeka products and in in-store promotions [75]. In Australia, a market with low consumer recognition of the MSC label, the pharmaceutical company Blackmores has developed a similar co-labelling arrangement with the WWF Panda on their Eco-Krill product, again with the intent of increasing consumer awareness [76]. In both these cases a licensing fee was paid to WWF by the company providing a funding arrangement for ongoing oceans campaigning in Germany and Australia. In the United States, also a market with poor consumer recognition of MSC, the Wild Selections brand has used co-labelling to raise recognition as well as establish a funding partnership with WWF with the express aim of funding US\$0.13 cents per product sold to finance Fishery Improvement Projects. 
Table 1. Examples of co-labelled Marine Stewardship Council (MSC) products.

\begin{tabular}{|c|c|c|c|c|}
\hline Product & $\begin{array}{l}\text { Co-labeled NGO } \\
\text { partner or initiative }\end{array}$ & Market & Strategy & Source \\
\hline $\begin{array}{c}\text { "Wild } \\
\text { Selections" }\end{array}$ & WWF & United States & $\begin{array}{l}\text { Increased market recognition of WWF in US market; US } \$ 0.13 \text { per product sold goes } \\
\text { to WWF funded fisheries improvement projects. }\end{array}$ & $\begin{array}{c}{[77]} \\
\text { Interview data }\end{array}$ \\
\hline $\begin{array}{l}\text { Edeka Brand- } \\
\text { Salmon, Cod, } \\
\text { fish fingers. }\end{array}$ & WWF & Germany & $\begin{array}{l}\text { WWF advises EDEKA since } 2009 \text { in its strategy to promote sustainable fisheries. In } \\
2015 \text { all fish sold should be sustainable, species under threat (eel, shark, etc.) are no } \\
\text { longer in the assortment. Sustainable fisheries and several WWF sea protection projects } \\
\text { are supported. }\end{array}$ & $\begin{array}{c}{[78],} \\
\text { Interview data }\end{array}$ \\
\hline Dutch Plaice & WWF & Germany & $\begin{array}{l}\text { Fishermen seeking additional market recognition through WWF Panda logo for } \\
\text { adopting additional voluntary measures to the conditions set out for MSC certification. }\end{array}$ & {$[9,79]$} \\
\hline $\begin{array}{l}\text { Blackmores } \\
\text { EcoKrill }\end{array}$ & WWF & Australia & $\begin{array}{l}\text { A three-year engagement to help Blackmores achieve the highest possible standard for } \\
\text { sustainable fish oils by } 2015 \text {, and represents Blackmores' commitment to fulfilling a } \\
\text { vision of healthy oceans, healthy communities and sustainable business practices. }\end{array}$ & $\begin{array}{c}{[76],} \\
\text { Interview data }\end{array}$ \\
\hline
\end{tabular}


In the final case in Table 1 the co-labeling of MSC and the WWF Panda was driven by Dutch Plaice fishers rather than retailers or brands. Here the MSC certified Dutch fishermen sought WWF-logo co-labeling as added recognition of a voluntary no-take zone established in addition to the conditions around modifying impacts to bottom trawl gears in order to be certified, for further detail see [79]. The implementation of these no-take zones had been a focal point of WWF advocacy to protect ecologically sensitive habitats in the North Sea. The fishermen deemed market recognition necessary because the Danish plaice fleet, which was certified after the Dutch fleet, did not adopt the same voluntary spatial measure despite an official complaint lodged to the MSC by WWF the Netherlands. In order to differentiate Dutch from Danish caught plaice, the Dutch fishers requested WWF Germany, a major market for their fish, to add the WWF panda logo to consumer products.

In all of these examples MSC-WWF co-labelling is arranged bilaterally between the companies (retailers, brands and fishers) and the national offices of WWF. Although MSC is aware of the co-labelling initiatives they are not involved in these commercial agreements. No formal agreement is in fact required between MSC and WWF to initiate co-labelling because of the independence of the licencing agreements with the companies. The only involvement MSC has is through its branding guidelines, which stipulate the use of the MSC label on products.

The co-labelling strategies of the companies and WWF appear to be in support of the MSC. Indeed, respondents from the MSC see co-labelling as a direct means of increasing consumer awareness and therefore meeting the wider advocacy goals of the organization. Seen as such the cases represent what Blackett and Russell [80] refer to as "values endorsement co-branding", where mutual benefits are gained from the "endorsement of one or the other's brand value and positioning or both" [80] (p. 10). However, although co-branding is designed to be constructive to the MSC, it also communicates the interests of brands and retailers attempting to go beyond the MSC requirements. For the Dutch fishermen it is no longer enough to "only" be MSC certified, and for the brands and retailers it is no longer enough to sell MSC certified products - they all require additional recognition afforded by WWF.

\subsection{MSC-Minus: FIPs and Pre-Certification Market Access}

Despite increases in the number of MSC certified "information poor" and "developing world fisheries" over time, they remain poorly represented; currently making up $8 \%$ of MSC certified fisheries, and $11 \%$ of fisheries in full assessment. The number of certified fisheries is set to increase with more than 40 developing world fisheries having undergone pre-assessment. But around half of fisheries that have move through to full assessment still derive from the North Atlantic [70]. The poor representation of developing world fisheries raises concerns around what improvements can be stimulated in different kinds of fisheries, given that an estimated $35 \%$ of fisheries that enter assessment already comply with the standards (ibid.).

In recent years non-governmental organizations (NGOs) and consultancy firms have begun to redress this situation through Fishery Improvement Projects (FIPs). FIPs are projects that support fisheries wishing to enter a pre-assessment or move from pre-assessment to full-assessment in MSC-certification. Between 400 and 500 developing world fisheries are estimated by the MSC (Pers. Comm. October 2014) to be involved in some kind of FIP with private sector and/or NGO partners, see also [81]. Recognizing that incentives for improvement also come through market or price incentives [82], FIPs have recently 
expanded beyond providing technical support to creating "partnerships" between fishers, processors and retailers to reward improved fishing practices through the market. Examples include the WWF supported Seafood Savers platform and the wider activities of the Sustainable Fisheries Partnership (SFP), both of which have partnered FIP fishers with retailers in Europe and the US. In doing so these market-oriented FIPs have created market opportunities for fisheries that are not currently able to obtain MSC certification but aspire to do so.

Major North American, UK and European retailers and brands, including those listed in Table 2, have seen an opportunity in FIPs, by funding them as part of their corporate social responsibility programs and using them in line with their commitment to only sell MSC sustainable fish by a specified year-most commonly 2015. In the interim period these retailers and brands are setting up various arrangements for buying and selling "FIP fish" [83], often marketing them under "sustainable" in-house product lines with marketing slogans claiming commitments to "support the development of sustainable fisheries". For example, John West will only use the Marine and Aquaculture stewardship Councils (MSC and ASC) certified products and "seafood products sourced from a fishery or aquaculture operation which is the subject of an improvement project recognized by WWF" [84]. Where these fish are marketed in a product assortment along with certified fish, consumers are confronted with two categories of "sustainability": MSC certified fisheries and fisheries "moving towards sustainability" supported by downstream value chain actors.

Although these FIPs provide a pathway to bridge credibility and accessibility of developing world and/or small-scale fisheries to international markets, they also drive a process of differentiation of the MSC label outside the control of the MSC itself. Just as certified fisheries and brands are requesting added recognition for going beyond MSC requirements, FIP fisheries are asking credit for taking a first step on the path to MSC certification. Both may have a case, but the impact of further differentiating "sustainability" may create unfamiliar challenges for MSC and consumers. The rest of the paper discusses these challenges and the consequences they might hold for the position and role of MSC in the global fish chain. 
Table 2. Examples of value chain supported Fisheries Improvement Projects (FIPs).

\begin{tabular}{|c|c|c|c|c|c|}
\hline Lead firm & Stated goal & $\begin{array}{c}\text { Lead firm, } \\
\text { country }\end{array}$ & Fisheries & $\begin{array}{c}\text { Fishery } \\
\text { Improvement } \\
\text { Project (FIP) } \\
\text { provider }\end{array}$ & Source \\
\hline $\begin{array}{c}\text { Woolworths } \\
\text { Limited }\end{array}$ & $\begin{array}{l}\text { "Have all our wild-caught seafood range Marine } \\
\text { Stewardship Council (MSC) certified in the } \\
\text { long term" }\end{array}$ & $\begin{array}{l}\text { Retailer, } \\
\text { Australia }\end{array}$ & $\begin{array}{l}\text { - } \text { Northern Prawn Fishery, Australia } \\
\text { - Orange Roughy, South East Trawl Fishery } \\
\text { Industry Association } \\
\text { - Southern and Eastern Scalefish and } \\
\text { - Shark Fishery } \\
\text { - Overall assessment and guidance } \\
\end{array}$ & $\begin{array}{l}\text { Landcare Australia; } \\
\text { CSIRO; FRDC; } \\
\text { SFP and Taronga } \\
\text { Conservation } \\
\text { Society Australia }\end{array}$ & {$[85]$} \\
\hline John West & $\begin{array}{l}\text { "Ultimately this partnership will see all John West } \\
\text { Australia products responsibly sourced. By the end } \\
\text { of } 2015 \text {, all John West Australia products will have } \\
\text { full traceability procedures demonstrating they are } \\
\text { sourced from MSC certified fisheries" }\end{array}$ & $\begin{array}{c}\text { Brand, } \\
\text { Australia }\end{array}$ & $\begin{array}{l}\text { - Pacific Islands conservation project - in the } \\
\text { Solomon Islands and Papua New Guinea } \\
\text { - Maldives funding a specialist to help a tuna } \\
\text { fishery there stay sustainable and maintain } \\
\text { its Marine Stewardship Council certification. }\end{array}$ & WWF & [84] \\
\hline $\begin{array}{c}\text { Wild } \\
\text { Selections }\end{array}$ & $\begin{array}{l}\text { "Wild selections are MSC certified sustainably } \\
\text { caught seafood that is supporting World Wildlife } \\
\text { Fund's efforts to protect marine life and expand } \\
\text { sustainable fishing practices globally. Wild } \\
\text { Selections }{ }^{\circledR} \text { will donate } 13 \text { cents from the sale of } \\
\text { each can, and a minimum total of } \$ 1,000,000 \text { by } \\
2018 \text {, to support WWF and their goal of securing } \\
\text { our oceans' future." }\end{array}$ & $\begin{array}{c}\text { Brand, } \\
\text { United States }\end{array}$ & - Tuna; salmon; sardines; shrimp & WWF & $\begin{array}{l}\text { [77], } \\
\text { Interview } \\
\text { data }\end{array}$ \\
\hline
\end{tabular}


Table 2. Cont.

\begin{tabular}{|c|c|c|c|c|c|}
\hline Lead firm & Stated goal & Lead firm, country & Fisheries & $\begin{array}{l}\text { Fishery Improvement } \\
\text { Project (FIP) provider }\end{array}$ & Source \\
\hline $\begin{array}{l}\text { Walmart } \\
\text { Canada }\end{array}$ & $\begin{array}{l}\text { "Walmart Canada's commitment is to ensure all } \\
\text { seafood sold in our stores is sourced from fisheries that } \\
\text { are MSC certified, managed in accordance with the } \\
\text { Principles of Credible Sustainability Programs } \\
\text { developed by The Sustainability Consortium; or have } \\
\text { entered into a credible fishery improvement project } \\
\text { (FIP) with clear goals and established timelines." }\end{array}$ & Retailer, Canada & $\begin{array}{l}\text { - Multiple species, in } \\
\text { particular tuna }\end{array}$ & $\begin{array}{c}\text { Sustainable Fisheries } \\
\text { Partnership; ISSF }\end{array}$ & {$[86]$} \\
\hline $\begin{array}{c}\text { National } \\
\text { Fisheries } \\
\text { Institute } \\
\text { Crab Council }\end{array}$ & $\begin{array}{l}\text { "Implement a multi-faceted FIP Work Plan that seeks } \\
\text { to address the MSC Framework including stock } \\
\text { assessments and management systems to ensure crab } \\
\text { stocks are productive, their ecosystems are intact, and } \\
\text { that the people whom are dependent on the fishery are } \\
\text { economically viable in the long term." }\end{array}$ & $\begin{array}{c}\text { Industry Association, } \\
\text { United States }\end{array}$ & $\begin{array}{l}\text { - Indonesian Blue } \\
\text { Swimming Crab }\end{array}$ & $\begin{array}{c}\text { SFP and Indonesia Blue } \\
\text { Swimming Crab Processors } \\
\text { Association (APRI) }\end{array}$ & {$[87,88]$} \\
\hline
\end{tabular}

Note: Selected to demonstrate the breadth of examples with publically available information. 


\section{Direct and Indirect Responses by MSC}

These two sets of externally led vertical differentiation, above and below the MSC certification threshold, have challenged the MSC to be more responsive to their value chain partners. While not going as far as adopting a new internal vertical differentiation associated with PI scores, the MSC has responded to these externally driven attempts at external differentiation by reviewing costs and developing new tools and procedures.

The MSC has responded directly to the emergence of FIPs by developing a benchmarking and tracking tool (BMT), designed to assess the progress of FIPs towards MSC pre-assessment [89]. In doing so the BMT responds to the ongoing critique that the MSC is inaccessible to fisheries well below the certification threshold. The BMT therefore provides a means of determining the status of FIPs and provides a means of measuring how far FIP fisheries are along the path to the pre-assessment and certification - should the end goal of a FIP indeed be compliance to the MSC standard, $c f$. [90,91]. The decision to develop the BMT by the MSC board was taken in response to two key value chain actors. First, fishers and the foundations and civil society groups supporting FIP activities expressed the need for a structured tool that could help monitor progress towards achieving the requisite score for all principle indicators. FIP managers have actively used the tool to set a plan for improvement as well as advocate the progress that has been made to market partners, e.g., [92]. Second, demand for the tool has also come from retailers, who have recognized the need to monitor the progress of those fisheries they are financially or otherwise supporting to achieve MSC certification. Many of the retailers involved started actively supporting FIPs shortly after making commitments to only sell MSC certified product from a specified date. While progress to this goal has been made in some countries with relatively small product assortments [93], retailers have continued to change the deadline of meeting this goal — from an initial pledge of 2012 to 2015 or later [94]. Faced with this challenge retailers have supported the development and use of the BMT to more clearly monitor the progress of those fisheries they support, or wish to buy from in the future.

A second response to the perceived inaccessibility of the MSC has been an internal cost review. The review has focused predominantly on efficiencies in the auditing process; the largest cost associated with pre-assessment, full assessment and re-assessment, ranging between US $\$ 15,000$ to US $\$ 300,000[95,96]$. As a result of the review, the MSC has identified potential cost reductions of the certification and re-certification of up to $50 \%$. However, these costs are not imposed by the MSC itself, but by auditors or so called "conformity assessment bodies" (CABs); and because of its independence from these CABs, the MSC is not able to directly mandate a change in the fees and costs of their commercial activities [97]. Instead the MSC has provided an instruction to the industry as a whole on how audits should be carried out, including guidance on the number of individuals that should be involved in an assessment and the number of days they should be able to complete their work. By providing this information the MSC has attempted to create greater transparency around all stages of certification, including pre, full and re-assessment. Further cost reductions have also been identified by the increased availability of assessment trees (developed by CABs) to fisheries entering assessment [98]. The result is a clearer basis for fisheries to question the decisions made by CABs in the allocation of their time and resources, and ultimately their cost structure. 
The third response, related to co-labelling, is less direct. The MSC currently has no policy regarding co-labelling - only guidelines on the requirements of applying the MSC label to a product [99]. In the cases analyzed above, co-labelling has been implemented at the behest of market partners wanting to gain greater traction in consumer markets by associating with the more widely recognized WWF Panda logo. The majority of these co-labelling strategies are limited to the introduction of a product in a market with low consumer recognition of the MSC label. However, new strategies are emerging - as illustrated by funding FIPs through WWF co-labelling on Wild Selections products. Although the response to co-labelling is limited by the licensing agreements of other parties, the current laissez faire approach to co-labelling appears to facilitate greater external control over how the MSC is publically represented. The short term gain to the MSC of value endorsement [80], market access and/or FIP funding may over the longer term undermine credibility if the MSC label is deemed ambiguous. Given the recent emergence of Fair Trade, and even organic certified fisheries, co-labelling strategies may even become more common-making the need for a clear co-labelling strategy perhaps all the more necessary.

\section{Discussion}

The results show how the MSC, as a private standard, is being challenged by the very networks it has played a role in creating. However, this challenge from both firm and non-firm actors in these networks has not resulted in a rejection of the MSC standard or its process of certification. Instead all of the actors involved are attempting to co-opt the credibility of the MSC to capture either market access or greater market value. The consequence of these actions is the emergence of a vertical differentiation of the standard both above and below the certification threshold outside the control of the standard owners. As such, the relationship of fishers and other value chain actors to the MSC is changing. The traditional role of those seeking certification as "passive standard takers" [38] appears to be changing to one of active "standard setters", and leading to the establishment of new sets of norms and expectations around the value and credibility of the MSC label. In response the MSC has adopted new strategies and tools that change their position from an independent "passive" standard owner, to one that is actively responding to these networks.

The first implication of this changing relationship is that the internal-external divide between standards and the subjects they seek to govern is becoming ambiguous. The structure and function of sustainability standards and certification processes have largely been related to the internal governance structure of the organizations, like the MSC, that own and manage them [60,61]. Whether or not the governance structure includes the norms and expectation of a broad set of subjects therefore determines the extent to which new issues will be taken up in the standards and process of certification. However, the rigidity of these governance structures can also lead to an inflexibility that prevents them from adequately responding to the exclusion of emerging concerns $[61,100]$. Our results extend this critique by showing that this internal inflexibility leads to external pressure on the standard, driven by alliances between retailers and NGOs that seek to circumvent the perceived inflexibility and limitations of the standard and certification process.

Second, the responses of the MSC to this external pressure also demonstrate the precarious relational nature of private authority and credibility in GVCs. To maintain authority and credibility private standards have to continually manage their relations with multiple actors, with the consequence that any 
changes will affect these relationships in different ways. For instance, while the BMT responds in part to concerns over the accessibility of fisheries involved in FIPs it does not influence the underlying value chain relations that have supported the proliferation of FIPs. Instead of facilitating entry to the market of fisheries "on the way to certification", it may be used by firms to lock fisheries into the MSC process [101]; especially as competing labels become more commonplace, or when fisheries and states perceive that they are being excluded [61,102,103]. Further investment in the technical assessment of FIPs may also pose a new kind of "pre-pre" assessment requiring further specialist expertise, and this in turn may fuel even more concern that certification remains inaccessible to small scale developing world fisheries. The cost review may appear to respond to growing concerns by various actors [81], but it's impact may be limited given that costs are ultimately decided by CABs and not the MSC. Similarly, by adopting a laissez-faire position on co-labelling, the MSC risks outsourcing control over the value endorsement to NGOs and firms. Therefore, while the MSC has sought to maintain its authority and credibility by responding to the norms and expectations of value chain actors, it has led to a range of new externalities associated with greater control by these actors over the standard and certification process.

What does this mean for the role and credibility of standard owners? Can they maintain their independence from the networks they themselves have developed, or should they engage with value chain actors more proactively? We argue, thirdly, that the examples in this paper demonstrate the changing power relations around certified fish in GVCs that are in turn driving vertical differentiation of the MSC standard outside the control of the MSC. The norms and expectations that were once used to justify MSC's regulation over the chain are now being subsumed by networks of fishers, retailers and NGOs and are driving the external vertical differentiation of the standard and certification process. Despite growing discontent, e.g., [104], there is still no radical shift away from the MSC given both its market and normative reputation. This sets up what Miller and Bush [105] refer to as a catch-22: the MSC risks their credibility if the norms and expectations of the networks that it governs are not appeased, but also if it enables firms and NGOs to re-qualify sustainability claims.

Our results are not limited to the MSC. Other standards are also facing challenges of externally-led vertical differentiation. In the global palm oil supply chain, the Roundtable for Sustainable Palm Oil (RSPO) has become a recognized sustainability standard [106,107]. However, discontent with the latest revision of the standard in 2013 drove WWF, one of the founders of the RSPO, to develop a stricter standard, the Palm Oil Innovations Group (POIG) with its own standard that builds on the RSPO standard but supplemented with additional critical issues [108]. Another illustration is organic certification in the Netherlands where over the years a national organic food label (EKO) has dominated the market, but the obligatory use of the EU organic food logo has made the EKO-label redundant. In response, the certifying body intends to build on the reputation of the EKO label as an indication "that the product is certified organic and moreover has been produced by a company that paid extra attention to sustainability" [109].

What these results ultimately show is that the emergence of any quality standard is not the predetermined reflection of a rational or scientific process, but instead a negotiated process open to social dynamics within and external to the supply chain. A lot of attention has been given to the co-creation of standards through MSI processes. However, what is less well understood is how this process of co-creation continues once the standard is released and functioning. We argue that this is a continual dynamic process, and one that makes standards open to feedback, negotiation and ultimately continued 
co-creation from those that they seek to govern. Placed into the wider context of GVCs, standards are not fixed but continually contested as the reciprocal effect from other shifts and changes in the strategies of firms and the global markets in which these firms operate. Recent value chain literature makes more of an attempt to understand this dynamic role and more should be made of it with regards to not only firms, but also the dynamic behavior of standards.

\section{Conclusions}

Using the case of the MSC we have shown that the differentiation of third-party environmental certification standards can be the result of interventions from supply chain actors and NGOs. When certification standards have acquired an established position in a market they become engaged in a dynamic process where chain actors and NGOs try to exert influence on the standard, the standardization procedure, and the labelling practice. This indicates that private environmental standards cannot remain immune from these dynamic interactions, and also that maintaining a status and reputation is an ongoing challenge. As such, the content of the standard and its implementation are all subject to decisions that standards have to make about how to balance their relationship with private sector partners and with other NGOs. Actively dealing with these external influences is a fundamental practice of any private certification scheme as it directly affects its reliability, accessibility and credibility both with consumers and the value chain actors they seek to govern. We argue that how responsive a scheme is and how successful it is in maintaining credibility are also key indicators of their long term effectiveness.

We also conclude that actively balancing the reliability, accessibility and credibility of the standard is a risky strategy for private environmental standards because, contrary to popular belief, they often occupy a relatively weak position in GVCs. In particular, the credibility of the standard may be undermined by a strategy of active engagement, because the more direct collaboration a standard has the more their independence will be eroded. As the MSC case illustrates, a more passive strategy may be more appropriate; engaging through the development of "arms-length" tools and protocols while leaving the implementation of these to others. The advantage of this responsive strategy is the maintenance of credibility and the private authority of the standard. However, the risk of this strategy is that such instruments will be used in ways independent of their original intent. Because the name and image of the private standard remains attached to these tools and protocols private standards may be forced to engage in controversy in the future which they are unable to control.

\section{Acknowledgments}

This research was partially supported by BESTTuna programme with funding from the Interdisciplinary Research Fund of Wageningen University. We thank Gert Spaargaren, Arthur Mol, Graham Auld, Maki Hatanaka, Doug Constance and two anonymous reviewers for their comments on earlier drafts of this paper.

\section{Author Contributions}

The authors contributed equally to the design of the study, analysis of the results research and writing of the manuscript. Both authors have read and approved the final manuscript. 


\section{Conflicts of Interest}

The authors declare no conflict of interest.

\section{References and Notes}

1. Cashore, B.; Auld, G.; Bernstein, S.; McDermott, C. Can Non-state Governance 'Ratchet Up' Global Environmental Standards? Lessons from the Forest Sector. Rev. Eur. Community Int. Environ. Law 2007, 16, 158-172.

2. Nadvi, K.; Wältring, F. Making Sense of Global Standards; Institut für Entwicklung und Frieden: Brighton, UK, 2002.

3. Marsden, T.K. Theorising food quality: Some issues in understanding its competitive production and regulation. In Qualities of Food; Harvey, M., McMeekin, A., Warde, A., Eds.; Manchester University Press: Manchester, UK, 2004; pp. 129-155.

4. Tallontire, A.; Opondo, M.; Nelson, V.; Martin, A. Beyond the vertical? Using value chains and governance as a framework to analyse private standards initiatives in agri-food chains. Agric. Hum. Values 2011, 28, 427-441.

5. Burch, D.; Dixon, J.; Lawrence, G. Introduction to symposium on the changing role of supermarkets in global supply chains: From seedling to supermarket: Agri-food supply chains in transition. Agric. Hum. Values 2013, 30, 215-224.

6. Tlusty, M.F. Environmental improvement of seafood through certification and ecolabelling: Theory and analysis. Fish Fish. 2012, 13, 1-13.

7. Our use of the term "vertical differentiation" differs to its use in explaining models of industrial organisation in economic theory. We do not use it to refer to specialisation, rice competition, quality and income sisparities, as it does in this wider literature; see [8].

8. Jaskold Gabszewicz, J.; Thisse, J.F. Price competition, quality and income disparities. J. Econ. Theory 1979, 20, 340-359.

9. Bush, S.R.; Toonen, H.; Oosterveer, P.; Mol, A.P.J. The 'devils triangle' of MSC certification: Balancing credibility, accessibility and continuous improvement. Mar. Policy 2013, 37, 288-293.

10. Ponte, S.; Sturgeon, T. Explaining governance in global value chains: A modular theory-building effort. Rev. Int. Polit. Econ. 2013, 21, 195-223.

11. Yeung, H.W.-C.; Coe, N.M. Toward a Dynamic Theory of Global Production Networks. Econ. Geogr. 2015, 91, 29-58.

12. Bush, S.R.; Oosterveer, P.; Bailey, M.; Mol, A.P.J. Sustainability Governance of Chains and Networks: A Review and Future Outlook. J. Clean. Prod. 2014, doi:10.1016/j.jclepro.2014.10.019.

13. Lund, C. Of what is this a case? Analytical movements in qualitative social science research. Hum. Organ. 2014, 73, 224-234.

14. Small, M.L. How to conduct a mixed methods study: Recent trends in a rapidly growing literature. Annu. Rev. Sociol. 2011, 37, 57-86.

15. Lemos, M.C.; Agrawal, A. Environmental Governance. Annu. Rev. Environ. Resour. 2006, 31, 297-325. 
16. Reardon, T.; Codron, J.-M.; Busch, L.; Bingen, J.; Harris, C. Global change in agrifood grades and standards: Agribusiness strategic responses in developing countries. Int. Food Agribus. Mgt. Rev. 2001, 2, 421-435.

17. Cashore, B. Legitmacy and the Privatization of Environmental Governance: How Non-State Market Driven (NSMD) Governance Systems Gain Rule-Making Authority. Gov. Int. J. Policy Adm. Inst. 2002, 15, 503-529.

18. Mutersbaugh, T. Fighting standards with standards: harmonization, rents, and social accountability in certified agrofood networks. Environ. Plan. A 2005, 37, 2033-2051.

19. Oosterveer, P. Global Governance of Food Production and Consumption: Issues and Challenges; Edward Elgar: Cheltenham, UK, 2007.

20. Ponte, S. Greener than Thou: The Political Economy of Fish Ecolabeling and Its Local Manifestations in South Africa. World Dev. 2008, 36, 159-175.

21. Hatanaka, M. Certification, Partnership, and Morality in an Organic Shrimp Network: Rethinking Transnational Alternative Agrifood Networks. World Dev. 2010, 38, 706-716.

22. Brunsson, N.; Rasche, A.; Seidl, D. The Dynamics of Standardization: Three Perspectives on Standards in Organization Studies. Organ. Stud. 2012, 33, 613-632.

23. Busch, L.; Bain, C. New! Improved? The Transformation of the Global Agrifood System. Rural Sociol. 2004, 69, 321-346.

24. Marsden, T.; Lee, R.; Flynn, A.; Thankappan, S. The New Regulation and Governance of Food: Beyond the Food Crisis? Routledge: London, UK, 2010.

25. Henson, S.; Humphrey, J. Understanding the complexities of private standards in global agri-food chains as they impact developing countries. J. Dev. Stud. JDS 2010, 46, 1628-1646.

26. Ponte, S., Gibbon, P., Vestergaard, J., Eds. Governing Through Standards: Origins, Drivers and Limitations; Palgrave Macmillan: London, UK, 2011.

27. Reinecke, J.; Manning, S.; van Hagen, O. The emergence of a standards market: Multiplicity of sustainability standards in the global coffee industry. Organ. Stud. 2012, 33, 791-814.

28. Fransen, L.U.C. Why Do Private Governance Organizations Not Converge? A Political-Institutional Analysis of Transnational Labor Standards Regulation. Governance 2011, 24, 359-387.

29. Parkes, G.; Young, J.A.; Walmsley, S.F.; Abel, R.; Harman, J.; Horvat, P.; Lem, A.; MacFarlane, A.; Mens, M.; Nolan, C. Behind the Signs-A Global Review of Fish Sustainability Information Schemes. Rev. Fisheries Sci. 2010, 18, 344-356.

30. Roheim, C.A. An Evaluation of Sustainable Seafood Guides: Implications for Environmental Groups and the Seafood Industry. Mar. Resour. Econ. 2009, 24, 301-310.

31. Jacquet, J.L.; Hocevar, J.; Lai, S.; Majuf, P.; Pelletier, N.; Pitcher, T.J.; Sala, E.; Sumaila, R.; Pauly, D. Conserving wild fish in a sea of market-based efforts. Oryx 2009, 44, 45-56.

32. Muradian, R.; Martinez-Alier, J. Trade and the environment: From a 'Southern' perspective. Ecol. Econ. 2001, 36, 281-297.

33. Ederington, J.; Minier, J. Is environmental policy a secondary trade barrier? An empirical analysis. Can. J. Econ. Rev. Canadienne D'économique 2003, 36, 137-154.

34. Heckelei, T.; Swinnen, J. Introduction to the Special Issue of the World Trade Review on 'standards and non-tariff barriers in trade'. World Trade Rev. 2012, 11, 353-355. 
35. Oosterveer, P.; Mol, A.P.J. Biofuels, trade and sustainability: A review of perspectives for developing countries. Biofuels Bioprod. Biorefining 2010, 4, 66-76.

36. Porter, G. Trade Competition and Pollution Standards: "Race to the Bottom" or "Stuck at the Bottom". J. Environ. Dev. 1999, 8, 133-151.

37. Riisgaard, L. Towards more stringent sustainability standards? Trends in the cut flower industry. Rev. Afr. Polit. Econ. 2011, 38, 435-453.

38. Nadvi, K. Global standards, global governance and the organization of global value chains. J. Econ. Geogr. 2008, 8, 323-343.

39. Gibbon, P.; Ponte, S. Trading Down: Africa, Value Chains and the Global Economy; Temple University Press: Philadelphia, PA, USA, 2005.

40. Ponte, S.; Ewert, J. Which Way is "Up" in Upgrading? Trajectories of Change in the Value Chain for South African Wine. World Dev. 2009, 37, 1637-1650.

41. Kaiser, M.J.; Edwards-Jones, G. The role of ecolabeling in fisheries management and conservation. Conserv. Biol. 2006, 20, 392-398.

42. Examples of tiered environmental certification systems include: The Global Aquaculture Alliance four star system. Available online: http://www.bestaquaculturepractices.org/ (accessed on 22 July 2014).

43. The US National Organic Standards. Available online: http://www.ams.usda.gov/AMSv1.0/nop (accessed on 22 July 2014).

44. The European Union energy label. Available online: http://www.energy.eu/\#energy-focus (accessed on 22 July 2014).

45. Gibbon, P.; Bair, J.; Ponte, S. Governing global value chains: An introduction. Econ. Soc. 2008, 37, 315-338.

46. Bair, J. Global Capitalism and Commodity Chains: Looking Back, Going Forward. Compet. Chang. 2005, 9, 153-180.

47. Gereffi, G.; Humphrey, J.; Sturgeon, T. The governance of global value chains: An analytic framework. Rev. Int. Polit. Econ. 2005, 12, 78-104.

48. Gibbon, P. Governance, Entry Barriers, Upgrading: A Re-Interpretation of Some GVC Concepts from the Experience of African Clothing Exports. Compet. Chang. 2008, 12, 29-48.

49. Overdevest, C.; Zeitlin, J. Assembling an experimentalist regime: Transnational governance interactions in the forest sector. Regul. Gov. 2014, 8, 22-48.

50. Bair, J. Global Commodity Chains: Genealogy and Review. In Frontiers of Commodity Chain Research; Bair, J., Ed.; Stanford University Press: Standford, CA, USA, 2009; pp. 1-34.

51. Ponte, S.; Gibbon, P. Quality standards, conventions and the governance of global value chains. Econ. Soc. 2005, 34, 1-31.

52. Giuliani, E.; Pietrobelli, C.; Rabellotti, R. Upgrading in Global Value Chains: Lessons from Latin American Clusters. World Dev. 2005, 33, 549-573.

53. Neilson, J.; Pritchard, B. Green Coffee? The Contradictions of Global Sustainability Initiatives from an Indian Perspective. Dev. Policy Rev. 2007, 25, 311-331.

54. McCarthy, J.F.; Gillespie, P.; Zen, Z. Swimming Upstream: Local Indonesian Production Networks in "Globalized" Palm Oil Production. World Dev. 2012, 40, 555-569. 
55. Ouma, S. Global Standards, Local Realities: Private Agrifood Governance and the Restructuring of the Kenyan Horticulture Industry. Econ. Geogr. 2010, 86, 197-222.

56. Tran, N.; Bailey, C.; Wilson, N.; Phillips, M. Governance of Global Value Chains in Response to Food Safety and Certification Standards: The Case of Shrimp from Vietnam. World Dev. 2013, 45, 325-336.

57. Busch, L. Standards: Recipes for Reality; The MIT Press: Cambridge, MA, USA, 2011.

58. Boström, M. Regulatory credibility and authority through inclusiveness: Standardization organizations in cases of eco-labelling. Organization 2006, 13, 345-367.

59. Green, J.F. Rethinking Private Authority: Agents and Entrepreneurs in Global Environmental Governance; Princeton University Press: Princeton, NJ, USA, 2013.

60. Gulbrandsen, L.H. Transnational Environmental Governance: The Emergence and Effects of the Certification of Forests and Fisheries; Edward Elgar: Cheltenham, UK, 2010.

61. Ponte, S. The Marine Stewardship Council (MSC) and the Making of a Market for 'Sustainable Fish'. J. Agrar. Chang. 2012, 12, 300-315.

62. MSC. Available online: http://www.msc.org/business-support/key-facts-about-msc (accessed on 9 September 2014).

63. MSC Fishery Standard: Principles and Criteria for Sustainable Fishing. Available online: http://www.nmfs.noaa.gov/ocs/mafac/meetings/2007_12/docs/msc_principles_and_criteria.pdf (accessed on 5 February 2015).

64. Ward, T.J. Barriers to biodiversity conservation in marine fishery certification. Fish Fish. 2008, 9 , $169-177$.

65. Gulbrandsen, L.H. The emergence and effectiveness of the Marine Stewardship Council. Mar. Policy 2009, 33, 654-660.

66. Jacquet, J.L.; Pauly, D. Trade secrets: Renaming and mislabeling of seafood. Mar. Policy 2008, 32, 309-318.

67. Asche, F.; Smith, M.D. Trade and fisheries: Key issues for the World Trade Organization. Available online: http://www.wto.org/english/res_e/reser_e/ersd201003_e.pdf (accessed on 5 February 2015).

68. Jacquet, J.L.; Pauly, D. The rise of seafood awareness campaigns in an era of collapsing fisheries. Mar. Policy 2007, 31, 308-313.

69. Froese, R.; Proelss, A. Evaluation and legal assessment of certified seafood. Mar. Policy 2012, 36, 1284-1289.

70. Cambridge, T.; Martin, S.; Nimmo, F.; Grieve, C.; Walmsley, S.; Huntington, T.; Cappell, R.; Agnew, D. Researching the Environmental Impacts of the MSC certification programme. Available online: http://www.msc.org/documents/environmental-benefits/measuring-environmentalimpacts-report-2011/environmental-impacts-of-the-msc-programme-full-report (accessed on 5 February 2015).

71. Agnew, D.; Grieve, C.; Orr, P.; Parkes, G.; Barker, N. Environmental Benefits Resulting from Certification against MSC's Principles and Criteria for Sustainable Fishing; Marine Resources Assessment Group (MRAG): London, UK, 2006. 
72. Marine Stewardship Council (MSC). Global Impacts Report 2013: Monitoring and Evaluation. Available online: http://www.msc.org/documents/environmental-benefits/global-impacts/mscglobal-impacts-report-2013 (accessed on 5 February 2015).

73. MSC New research reveals increasing consumer support for the MSC ecolabel.

74. OECD. Greening Household Behaviour. OECD Publishing 2014, doi:10.1787/9789264214651-en.

75. Translated from German by the authors. Available online: http://www.edeka.de/EDEKA/de/ edeka_zentrale/verantwortung/nachhaltigkeit/fisch_1/nachhaltiger_fisch.jsp (accessed on 13 October 2014).

76. Blackmores Blackmores and WWF Announce Sustainable Fish Oils Partnership. http:/www.blackmores.com.au/about-us/media-centre/media-releases/blackmores-and-wwfannounce-sustainable-fish-oils-partnership (accessed on 18 August 2014).

77. WildSelections Wild Selections FAQ. Available online: http://www.wildselections.com/ (accessed on 18 August 2014).

78. Fisch mit gutem Gewissen. Available online: https://www.test.de/Fisch-Mit-gutem-Gewissen4174425-0/ (accessed on 18 August 2014).

79. Toonen, H.M.; Mol, A.P.J. Putting sustainable fisheries on the map? Establishing no-take zones for North Sea plaice fisheries through MSC certification. Mar. Policy 2013, 37, 294-304.

80. Blackett, T.; Russell, N. What is co-branding? In Co-branding: The Science of Alliance; Blackett, T., Boad, R.W., Eds.; Palgrave Macmillan: London, UK, 1999; pp. 1-21.

81. Foley, P. The political economy of Marine Stewardship Council certification: Processors and access in Newfoundland and Labrador's inshore shrimp industry. J. Agrar. Chang. 2012, 12, 436-457.

82. Roheim, C.A.; Asche, F.; Insignares Santos, J. The Elusive Price Premium for Ecolabelled Products: Evidence from Seafood in the UK Market. J. Agric. Econ. 2011, 62, 655-668.

83. Note that not all FIPs are located in developing countries, although those fisheries to date have receive the most attention and support in the market. See SFP FIP Directory (accessed on 10 October 2014).

84. John West Our Commitment. Available online: http://johnwest.com.au/sustainability/our-oceansforever/our-commitment (accessed on 20 October 2014).

85. Woolworths Sustainable Fish and Seafood. Available online: http://www.woolworthslimited.com.au/ page/A_Trusted_Company/Responsibile_Sourcing/Sustainable_Fish_and_Seafood/ (accessed on 20 September 2014).

86. Walmart Canada's Commitment to Sustainable Seafood. Available online: http://walmartcanada.ca/ Pages/Sustainable\%20Seafood\%20Commitment/175/236/236 (accessed on 5 February 2015).

87. NFI Indonesia. Available online: http://www.committedtocrab.org/projects/indonesia/ (accessed on 18 August 2014).

88. Bokkes, F. Trade, information and perceptions in Fishery Improvement Projects: the case of the blue swimming crab fishery in Betahwalang, Indonesia. Available online: http://library.wur.nl/ WebQuery/clc/2049854 (accessed on 5 February 2015).

89. MSC Benchmarking and Tracking Tool (BMT): Guidance for benchmarking fisheries as they improve towards MSC certification. Available online: http:/www.msc.org/documents/ developing-world/benchmarking-and-tracking-tool/benchmarking-and-tracking-tool-guidancedocument (accessed on 5 February 2015). 
90. SFP Fisheries Improvement. Available online: http://www.sustainablefish.org/ fisheries-improvement (accessed on 10 October 2014).

91. WWF FIP Handbook: Guidelines for Developing Fishery Improvement Projects; WWF-US Fisheries Programme: 2013.

92. Habibi, A. Adopting Management Measures to Ensure the Health of Indonesia's Coastal Tuna Fisheries-Tuna Fishery Improvement Program. In Proceedings of the 3rd International Coastal Tuna Business Forum, Jakarta, Indonesia, 19-20 May 2014.

93. It is estimated that $85 \%$ of the fish available in Dutch retailers is now MSC certified; see LEI Monitor Duurzaam Voedsel 2013: Consumentenbestedingen aan duurzaam gelabelde producten; Netherlands Ministry of Economic Affairs: The Hague, 2014. However, it is notable that no more than five capture fishery species on their shelves.

94. Fiorillo, J. Are the World's Retailers and Restaurants Delivering on their Sustainable Seafood Promises? Available online: http://www.intrafish.com/free_news/article1394271.ece (accessed on 5 February 2015).

95. Christian, C.; Ainley, D.; Bailey, M.; Dayton, P.; Hocevar, J.; LeVine, M.; Nikoloyuk, J.; Nouvian, C.; Velarde, E.; Werner, R. A review of formal objections to Marine Stewardship Council fisheries certifications. Biol. Conserv. 2013, 161, 10-17.

96. Goyert, W.; Sagarin, R.; Annala, J. The promise and pitfalls of Marine Stewardship Council certification: Maine lobster as a case study. Mar. Policy 2010, 34, 1103-1109.

97. Hatanaka, M.; Bain, C.; Busch, L. Third-party certification in the global agrifood system. Food Policy 2005, 30, 354-369.

98. An Assessment Tree is a translation made by CABs of the principles and principles indicators into the context of a specific fishery. These trees can be transferred between species and gears and then again adapted for the specific context of a fishery increasing the efficiency of the translation of principles; see MSC Marine Stewardship Council Fisheries Assessment Methodology and Guidance to Certification Bodies. Available online: http://www.msc.org/documents/schemedocuments/msc-scheme-requirements/methodologies/Fisheries_Assessment_Methodology.pdf (accessed on 5 February 2015).

99. MSC Ecolabel User Guide. Available online: http://www.msc.org/documents/logo-use/mscecolabel-user-guide (accessed on 5 February 2015).

100. Hatanaka, M. Governing sustainability: Examining audits and compliance in a third-party-certified organic shrimp farming project in rural Indonesia. Local Environ. 2010, 15, 233-244.

101. Roe, B.E.; Teisl, M.F.; Deans, C.R. The Economics of Voluntary Versus Mandatory Labels. Ann. Rev. Resour. Econ. 2014, 6, 407-427.

102. Gulbrandsen, L.H. Dynamic governance interactions: Evolutionary effects of state responses to non-state certification programs. Regul. Gov. 2014, 8, 74-92.

103. Foley, P. National Government Responses to Marine Stewardship Council (MSC) Fisheries Certification: Insights from Atlantic Canada. New Polit. Econ. 2012, 18, 284-307.

104. Foley, P.; Hébert, K. Alternative regimes of transnational environmental certification: Governance, marketization, and place in Alaska's salmon fisheries. Environ. Plan. A 2013, 45, 2734-2751.

105. Miller, A.M.; Bush, S.R. Authority without credibility? Competition and conflict between ecolabels in tuna fisheries. J. Clean. Prod. 2014, doi:10.1016/j.jclepro.2014.02.047. 
106. Schouten, G.; Glasbergen, P. Creating legitimacy in global private governance: The case of the Roundtable on Sustainable Palm Oil. Ecol. Econ. 2011, 70, 1891-1899.

107. Oosterveer, P. Promoting Sustainable Palm Oil; Viewed from a Global Networks and Flows Perspective. J. Clean. Prod. 2014, doi:10.1016/j.jclepro.2014.01.019.

108. See the Palm Oil Innovations group Charter on www.poig.org (accessed on 21 November 2014).

109. EKO-website. Available online: www.eko-keurmerk.nl/eko-quality-mark-for-products/consumer (accessed on 16 December 2014). See also: Anon. (2012) Verdringt verplicht EU bio-logo het EKO-keurmerk? (Is the obligatory EU organic label crowding out the EKO-label?) AGF Primeur (8), p. 62.

(C) 2015 by the authors; licensee MDPI, Basel, Switzerland. This article is an open access article distributed under the terms and conditions of the Creative Commons Attribution license (http://creativecommons.org/licenses/by/4.0/). 